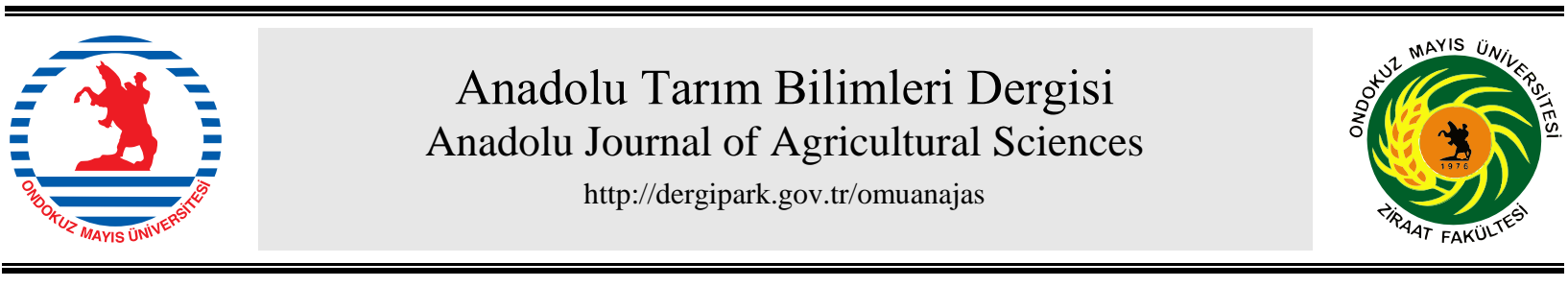

Araştırma/Research

Anadolu Tarım Bilim. Derg./Anadolu J Agr Sci, 32 (2017)

ISSN: 1308-8750 (Print) 1308-8769 (Online)

doi: 10.7161/omuanajas.309651

\title{
Farklı substrat ve besin çözeltisi miktarının domates bitkisinin azot, fosfor ve potasyumdan yararlanma oranına etkisi
}

\author{
Güney Akınoğlu*, Ahmet Korkmaz, Ayhan Horuz \\ Ondokuz Mayls Üniversitesi Ziraat Fakültesi Toprak Bilimi ve Bitki Besleme Bölümü, 55139 Atakum, Samsun \\ *Sorumlu yazar/corresponding author: guney_akinoglu@ymail.com
}

Geliş/Received 28/04/2017 Kabul/Accepted 18/09/2017

\begin{abstract}
ÖZET
Bu çalışmanın amacı, 1:1 torf:perlit karışımında $600 \mathrm{~g}$ az (SA), $1030 \mathrm{~g}$ orta (SO) ve $1490 \mathrm{~g}$ fazla (SF) katı ortam kültürüne uygulanan günlük 75, 125, 175 ve $225 \mathrm{~mL}$ besin çözeltisinin domates bitkisinin $\mathrm{N}$, $P$ ve K'dan yararlanma oranına etkisini belirlemektir. Deneme sera şartlarında $3 \mathrm{x} 4$ faktöriyel deneme desenine göre 3 tekerrürlü olarak yürütülmüştür. Elde edilen verilere göre substrat miktarı azaldıkça meyvenin besin çözeltisi ile verilen azottan yararlanma oranında artış görülmüştür. Meyvede en düşük azottan yararlanma oranı $1490 \mathrm{~g}$ substrat ortamında $75 \mathrm{~mL}$ besin çözeltisi uygulandı̆̆ında elde edilmiştir. Meyvede azot ve fosfordan en yüksek yararlanma oranı $600 \mathrm{~g}$ katı ortamda $125 \mathrm{~mL}$ besin çözeltisi uygulamasında elde edilmiştir. Sapta azottan ve meyve+sapta fosfordan optimum yararlanma oranları için uygun besin çözeltisi miktarları substrat miktarlarına göre değişmiştir. Besin çözeltisine verilen potasyumdan sapta yararlanma oranı meyvede yararlanma oranına ilişkin değerlerden düşük bulunurken; meyve ve sapta potasyumdan yararlanma oranına ilișkin değerler substrat miktarı ve günlük besin çözeltisi miktarına bağlı bulunmuştur. Domates bitkisine verilen azottan meyvede yararlanma oranı 75, 125 ve $175 \mathrm{~mL}$ besin çözeltisi uygulandığında katı ortam miktarlarına göre $\mathrm{SA}>\mathrm{SO}>\mathrm{SF}$ şeklinde sıralanmıştır.
\end{abstract}

Effect of different substrate and nutrition solution amount on nitrogen, phosphorus and potassium use efficiency of tomato

\section{ABSTRACT}

The purpose of this study is to determine the effect of 75, 125, 175 and $225 \mathrm{~mL}$ of nutrient solution amount applied daily in $600 \mathrm{~g}$ low (SA), $1030 \mathrm{~g}$ medium (SO) and $1490 \mathrm{~g}$ excess (SF) solid substrat media consisting of 1:1 peat:perlite mixture on the nutrient $\mathrm{N}, \mathrm{P}$ and $\mathrm{K}$ use efficiency of tomato plant. This experiment was carried out according to the $3 \times 4$ factorial experimental design with 3 replications. It was observed that use efficiency of nitrogen supplied from nutrient solution $f$ increased with decreasing substrate amount.The lowest nitrogen use efficiency was obtained when $75 \mathrm{~mL}$ nutrient solution was applied on $1490 \mathrm{~g}$ substrate medium. The highest nitrogen and phosphorus use efficiency in tomato fruit was obtained when $125 \mathrm{~mL}$ of nutrient solution was applied on $600 \mathrm{~g}$ of solid medium. Available nutrient solution amounts for optimum nitrogen use efficiency in stem and optimum use efficiency in fruit + stem were found to be dependent on substrate amounts. The potassium use efficiency in stem has been found to be lower than the potassium use efficiency in fruit. The values of potassium use efficiency in fruit and stem were not related to the amount of substrate but they were affected by the amount of daily supply of nutrient solution. The nitrogen use efficiency by tomato fruit according to substrate amounts is ranked as SA>SO>SF when applied 75, 125 and $175 \mathrm{~mL}$ of nutrient solution.

\section{Giriş}

Topraksız yetiştiricilikte besin çözeltisi uygulamaları daha kontrollü yapıldığından ve ayrıca verilen besin elementlerinin fikse olması gibi durumlar söz konusu olmadığından dolayı besin çözeltisi ile uygulanan
Anahtar Sözcükler:

Katı ortam

Domates

Substrat miktarı

Günlük besin çözeltisi

hacmi

NPK kullanım

etkinliği
Keywords:
Solid media
Tomato
Substrate amount
Daily nutrient Solution
amount
NPK use efficiency

elementlerden bitkiler daha hızlı ve fazla oranda yararlanabilmektedir. Genel olarak bitkilerin uygulanan gübrelerden yeterince yararlanabilmesi ve gübrelerin kullanım etkinlikleri çok sayıda faktöre bağlı bulunmaktadır (Baligar, 2001). Bunlardan başlıcaları:1) Toprak faktörü 2) Biyolojik faktör 3) Bitki faktörü 4) 
Bitki besleme yönetim stratejisi 5) Agronomik faktörler 6) İklimsel faktörlerdir 7) Azotlu gübrelerin gaz şeklinde uçması ya da nitrat formunda yıkanması 8) Gübreleme zamanı ve yöntemleri. Söz konusu faktörler dikkate alınarak yapılan gübre uygulamaları ile gübre kullanım etkinliğinde önemli artışlar kaydedilmiştir (Alam ve ark., 2003; Gerendas ve ark., 2008). Karaman ve Turan (2012) gübre kullanım etkinliğini azaltan çok sayıda faktör bulunduğunu ve bu faktörlerin gübre kullanım etkinliğini azaltma oranlarını aşağıdaki gibi belirtmişlerdir:

1) Uygun olmayan tohum yatağının gübre kullanım etkinliğini azaltma oranı \% 10-20,

2) Uygun olmayan bitki çeşidinin gübre kullanım etkinliğini azaltma oranı \% 20-40

3) Ekim ve dikimde geç kalmanın gübre kullanım etkinliğini azaltma oran $1 \% 20-40$

4) Erken dikim ve ekimin kullanım etkinliğini azaltma oran $1 \% 5-20$

5) Yetersiz sulamanın kullanım etkinliğini azaltma oran1 \% 10-20

6) Hastalıkların kullanım etkinliğini azaltma oranı $\% 15-20$

7) Zararlıların kullanım etkinliğini azaltma oranı $\%$ 5-50

8) Bilinçsiz gübre uygulamasının gübre kullanım etkinliğini azaltma oranı $\% 20-50$

9) Yanlış gübre uygulama zamanının gübre kullanım etkinliğini azaltma oranı \% 5-10'dur.

Bilhassa gübre uygulama zamanının ve miktarının gübre etkinliğini önemli ölçüde etkilediğini ve kök gelişme ortamında zayıf strüktür, düşük veya yüksek su tutma kapasitesi gibi fiziksel özelliklerdeki olumsuzluklarda gübreleme etkinliğini azalttığını belirtmişlerdir (Adiloğlu ve Eraslan, 2012). Aynı yazarlar gübre kullanım etkinliği üzerinde kimyasal ve organik gübre çeşitlerinin, uygulanan gübre dozlarının, uygulama zamanları ve yöntemlerinin etkilerinin önemli olduğunu da bildirmişlerdir. Besin element kaybındaki azalmaların gübre kullanım etkinliğini arttırdığı $(\mathrm{Li}$ ve ark., 2001), ihtiyacın üzerinde verilen gübrenin ortamda birikmesine veya yıkanmasına ve verimin azalmasına neden olabileceği, gübrenin ihtiyacın altında verilmesi halinde ise verim düşüklüğüne neden olacağı ifade edilmiştir (Karaman ve ark., 2008).

Besin elementleri arasındaki etkileşimler (antagonizm $=$ olumsuz etkileşim, sinergizm $=$ olumlu etkileşim) ve diğer bitkisel faktörlerde gübre kullanım etkinliği açısından önemlidir (Karaman ve ark.,2006). Bitki çeşidi ve hatta aynı çeşidin farklı genotipleri arasında dahi besin elementi alım ve kullanım etkinliğinin değiştiği belirlenmiştir (Karaman ve Turan, 2012).Gübre kullanım etkinliği, bitkilerin besin elementlerini alım gücü olarak ifade edilebilir. Genellikle azot (N) için bu değer \% 40-60 arasında, fosfor (P) için \% 20-30 arasında, potasyum (K) için $\%$ 65-80 arasında değişmektedir. En yüksek etkinlik çoğunlukla besin elementi noksanlığı görülen ortamlara uygulanan gübrelerden elde edilir (Karaman, 2012). Değişen koşullara göre bitki besleme yönetim stratejilerin doğru belirlenmesi ve farklı bitkilerin gübre kullanım etkinliklerinin bilinmesi gübrelemeden beklenen yararın elde edilebilmesi için son derece önemlidir. Etkinlik kavramlarının tarımda temel kullanım amacı ise gübrelerin daha bilinçli, ekonomik ve dolayısıyla etkin kullanımlarının sağlanmasıdır (Karaman ve Turan, 2012). Korkmaz ve ark. (1991) çeltikte ${ }^{15} \mathrm{~N}$ etiketli üre gübresi uygulayarak yaptıkları çalışmada; çeltiğin gelişme dönemine bağlı olarak üreden yararlanma oranının değiştiği, en yüksek yararlanmanın başaklanma döneminde verilen üreden sağlandığı ve ayrıca her dönemdeki tatbik edilen üre miktarının değişmesi ile ürenin yararlanma oranında önemli değişiklikler oluştuğunu bildirmişlerdir. Fertigasyon yoluyla gübre kullanım etkinliği büyük ölçüde arttırılabilmektedir (Schepers ve ark., 1995). Geleneksel yöntemlerle fertigasyonun kıyaslandığ çalışmalarda fertigasyonla gübre kullanım etkinliğinin \%20-50 daha fazla olduğu bildirilmektedir (Gaskell, 2004).

Bu çalışmanın amacı, katı ortam kültüründe substrat ve günlük uygulanan besin çözeltisi hacminin domates bitkisinin NPK'dan yararlanma oranına etkisini belirlemektir.

\section{Materyal ve Yöntem}

\subsection{Deneme}

Çalışmada1:1 torf-perlit karışımından hazırlanan katı ortam kültüründen 3 litrelik saksılara 1490 ve 1030 $\mathrm{g}, 2$ litrelik saksılara ise $600 \mathrm{~g}$ konularak yürütülmüştür. Katı ortam kültür miktarı SA:600 g az, SO:1030 g orta ve SF:1490 g fazla olarak değerlendirilmiştir. Farklı miktardaki her 3 ortama günlük bitki başına 75,125 , 175 ve $225 \mathrm{~mL}$ besin çözeltisi $3 \times 4$ faktöriyel deneme deseni planına göre 3 tekerrürlü olarak uygulanmıştır. Buna göre denemede toplam 36 saksı kullanılmıştır. Denemede drenajı sağlamak için saksıların dipleri delinmiştir. Denemede Tybiff Aq domates çeşiti (Lycopersicon esculentum) fideleri her saksiya 31.03.2014 tarihinde bir adet olacak şekilde dikilmiştir. Denemede sulamalar besin çözeltisi ve ilave sulama suyu kullanılarak yapılmıştır. Gerek besin çözeltisi hazırlanmasında gerekse sulamada kullanılan suyun pH's1 7.68 olup elektriksek iletkenlik (EC) değeri 0.42 $\mathrm{dS} / \mathrm{m}$ 'dir. Ayrica sulama suyu $35.06 \mathrm{mg} \mathrm{L}^{-1}$ kalsiyum (Ca), 11,08 $\mathrm{mg} \mathrm{L}^{-1}$ magnezyum (Mg), $0.02 \mathrm{mg} \mathrm{L}-1$ çinko (Zn) içermektedir. Saksılar erken dönemlerde her gün tartılarak ortam miktarlarına bağlı olarak tarla kapasitesinde tutulmuştur. Ortam miktarı azaldıkça tarla kapasitesine getirmek için verilen su miktarı azalmıştır. Bitkinin ileri dönemlerinde tartım yapılamadığı için çok az bir yıkanma (\%10-20'lik bir yıkanma) olacak şekilde besin çözeltisi uygulamalarından sonra ilave olarak sulama yapılmıştır. Denemede dikimden meyve tutum başlangıcına kadar (39 gün) ve meyve tutum 
başlangıcından hasata kadar (45 gün) aşağıda verilen konsantrasyonlarda Gül (2008)'in bildirdiği Hoogland besin çözeltisi uygulanmıştır (Çizelge 1).Meyve tutum döneminden itibaren hasata kadar (45 gün) geçen süre boyunca fosfor ve potasyum konsatrasyonları artııılmıştır. Besin çözeltilerinin hazırlanmasında kalsiyum nitrat tetrahidrat $\left(\mathrm{Ca}\left(\mathrm{NO}_{3}\right)_{2} \cdot 4 \mathrm{H}_{2} \mathrm{O}\right)$, amonyum nitrat $\left(\mathrm{NH}_{4} \mathrm{NO}_{3}\right)$, potasyum nitrat $\left(\mathrm{KNO}_{3}\right)$, magnezyum sülfat heptahidrat $\left(\mathrm{MgSO}_{4} \cdot 7 \mathrm{H}_{2} \mathrm{O}\right)$, potasyum dihidrojen fosfat $\left(\mathrm{KH}_{2} \mathrm{PO}_{4}\right)$; demir-etilen diamindihidroksifenilasetik asit (Fe-EDDHA), mangan sülfat monohidrat $\left(\mathrm{MnSO}_{4} \cdot \mathrm{H}_{2} \mathrm{O}\right)$, borik asit $\left(\mathrm{H}_{3} \mathrm{BO}_{3}\right)$, bakır sülfat pentahidrat $\left(\mathrm{CuSO}_{4} \cdot 5 \mathrm{H}_{2} \mathrm{O}\right)$, çinko sülfat heptahidrat $\quad\left(\mathrm{ZnSO}_{4} \cdot 7 \mathrm{H}_{2} \mathrm{O}\right), \quad$ amonyum molibdattetrahidrat $\quad\left[\left(\mathrm{NH}_{4}\right)_{6} \mathrm{Mo}_{7} \mathrm{O}_{24} \cdot 4 \mathrm{H}_{2} \mathrm{O}\right]$ kullanılmıştır.

Çizelge 1. Domates bitkisine verilen besin çözeltisinde element konsantrasyonu (Gül, 2008)

\begin{tabular}{ccc}
\hline \multirow{2}{*}{ Element } & \multicolumn{2}{c}{ Konsantrasyon $\left(\mathrm{mg} \mathrm{L}^{-1}\right)$} \\
\cline { 2 - 3 } & $\begin{array}{c}\text { Dikim-meyve } \\
\text { tutum başlangic1 }\end{array}$ & $\begin{array}{c}\text { Meyve tutum } \\
\text { başlangic1-hasat }\end{array}$ \\
\hline $\mathrm{N}$ & 242 & 242 \\
$\mathrm{P}$ & 31 & 54 \\
$\mathrm{~K}$ & 234 & 263 \\
$\mathrm{Ca}$ & 160 & 160 \\
$\mathrm{Mg}$ & 48 & 48 \\
$\mathrm{Fe}$ & 2.5 & 2.5 \\
$\mathrm{Mn}$ & 0.5 & 0.5 \\
$\mathrm{~B}$ & 0.5 & 0.5 \\
$\mathrm{Cu}$ & 0.02 & 0.02 \\
$\mathrm{Zn}$ & 0.05 & 0.05 \\
$\mathrm{Mo}$ & 0.01 & 0.01 \\
\hline
\end{tabular}

Miktarları farklı her 3 ortama vegetatif ve generatif dönemlerde domates bitkisine günlük uygulanan besin çözeltisi miktarlarına bağlı olarak toplam uygulanan besin element miktarları hesap edilmiştir. Deneme 20.06.2014 tarihinde hasat edilmiş bitki başına taze meyve ağırlıkları, meyve sayısı ve ortalama meyve ağırlığı muamele konularına bağlı olarak tespit edilmiştir. Muamele konularına bağlı olarak bitkinin gövde ve yaprakları ayrı ayrı $65^{\circ} \mathrm{C}$ 'de kurutularak gövde+yaprak kuru madde miktarları belirlenmiştir. Taze meyve örnekleri de $65^{\circ} \mathrm{C}$ 'de kurutulmuş ve ayrıca muamele konularına bağlı olarak bitki başına kuru madde miktarları tespit edilmiştir.

\subsection{Bitki analizleri}

Kurutulmuş sap ve meyve örnekleri çelik değirmende ögütüldükten sonra toplam $\mathrm{N}$ mikro kjeldahl metodu ile fosfor bartın sarı renk metoduna göre kolorimetrik olarak spektrofotometrede (JENWAY 7320D) ve potasyum atomik absorpsiyon sapektrofofometresinde (PERKIN ELMER AA 200) Kacar ve İnal (2008)'ın bildirdiği şekilde belirlenmiştir. Kuru meyve ve sap ile kaldırılan besin elementi miktarları $\left(\mathrm{g} \mathrm{saks1}^{-1}\right)$ hesap edilmiştir. Ayrıca N, P ve K için muamele konularına bağlı olarak toplam verilen $\mathrm{N}$, $P$ ve K'dan meyvenin, sapın ve meyve+sapın toplam yararlanma oranları aşağıdaki formülle belirlenmiştir:

$\%$ Yararlanma oranı $=($ Kaldırılan element miktarı, $\mathrm{g} / \mathrm{saks}$ /Toplam verilen element miktarı, g/saksı) x 100

\subsection{Istatistiksel analizler}

Elde edilen veriler SPSS 17.0 paket programı kullanılarak varyans analizine tabi tutulmuş ve muamele konularına ilişkin ortalamalar en küçük anlamlı fark testi (LSD) ile \%5 seviyesinde karşılaştırılmıştır (Yurtsever, 1982).

\section{Bulgular ve Tartışma}

\subsection{Yem hammaddeleri kompozisyonu}

\subsection{Substrat ve günlük uygulanan besin çözeltisi miktarınin domates bitkisinde $N, P, \quad K$ ' dan yararlanma oranina etkisi}

Substrat ve günlük uygulanan besin çözeltisi miktarının domates bitkisinde meyvede, sapta ve meyve+sapta N'dan yararlanma oranına etkisine ilişkin değerler Çizelge 2'de verilmiştir.

Günlük 75, 125 ve $175 \mathrm{~mL}$ besin çözeltisi uygulamalarında verilen azottan meyvenin yararlanma oranına ilişkin değerler substrat miktarına(SA:600 g az, SO:1030 g orta ve SF: 1490 fazla) bağlı olarak $\mathrm{SA}>\mathrm{SO}>\mathrm{SF}$ şeklinde sıralanmıştır. Substrat miktarı azaldıkça besin çözeltisi ile verilen azottan meyvenin yararlanma oranında artış görülmüştür. $225 \mathrm{~mL}$ günlük uygulanan besin çözeltisi uygulamasında ise SF $>$ SO $>$ SA şeklinde sıralanmıştır. Meyvede azottan yararlanma oranı en yüksek $600 \mathrm{~g}$ substrat ortamında günlük $125 \mathrm{~mL}$ besin çözeltisi uygulandığında elde edilmiştir. Meyvede azottan yararlanma oranı en düşük $1490 \mathrm{~g}$ substrat ortamında $75 \mathrm{~mL}$ besin çözeltisi uygulandığında elde edilmiştir (Şekil 1).

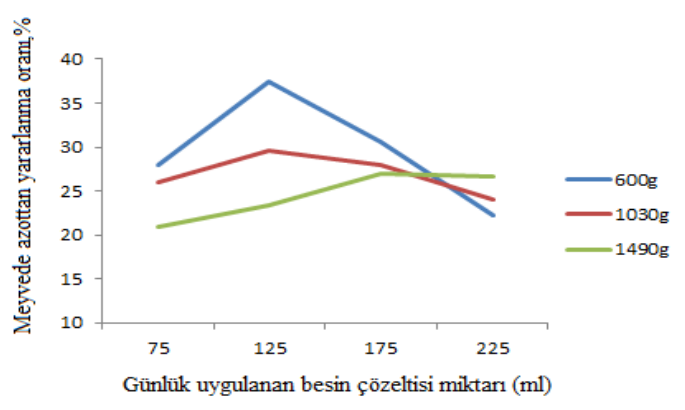

Şekil 1. Farklı miktarda substrat ortamında günlük uygulanan besin çözeltisi miktarının meyvede azottan yararlanma oranına etkisi 
Çizelge 2. Substrat ve günlük uygulanan besin çözeltisi miktarının domates bitkisinde meyvede, sapta ve meyve+sapta azottan yararlanma oranına etkisi

\begin{tabular}{|c|c|c|c|c|c|c|c|c|c|c|c|c|}
\hline \multirow{3}{*}{$\begin{array}{c}\text { Günlük } \\
\text { besin } \\
\text { çözeltisi } \\
\text { miktarı (ml) }\end{array}$} & \multicolumn{4}{|c|}{ Meyvede N yararlanma oranı, \% } & \multicolumn{4}{|c|}{ Sapta N yararlanma oranı, \% } & \multicolumn{4}{|c|}{ Meyve+sapta N yararlanma oranı, \% } \\
\hline & \multicolumn{4}{|c|}{ Substrat miktarı $\left(\mathrm{g} \mathrm{saks1}^{-1}\right)$} & \multicolumn{4}{|c|}{ Substrat miktarı $\left(\mathrm{g} \mathrm{saks1}^{-1}\right)$} & \multicolumn{4}{|c|}{ Substrat miktarı $\left(\mathrm{g} \mathrm{saks1}^{-1}\right)$} \\
\hline & 1490 & 1030 & 600 & Ort. & 1490 & 1030 & 600 & Ort. & 1490 & 1030 & 600 & Ort. \\
\hline 75 & $20.9 \mathrm{e}$ & $26.0 \mathrm{bcde}$ & $28.0 \mathrm{bcde}$ & $24.8 \mathrm{C}$ & $59.1 \mathrm{~b}$ & $56.0 \mathrm{c}$ & $66.1 \mathrm{a}$ & $60.4 \mathrm{~A}$ & 79.9 & 82.1 & 90.0 & $84.0 \mathrm{~A}$ \\
\hline 125 & $23.4 \mathrm{cde}$ & $29.6 \mathrm{bc}$ & $37.4 \mathrm{a}$ & $30.1 \mathrm{~A}$ & $44.2 \mathrm{e}$ & $44.0 \mathrm{e}$ & $51.9 \mathrm{~d}$ & $46.0 \mathrm{~B}$ & 67.5 & 73.6 & 89.4 & $76.8 \mathrm{~B}$ \\
\hline 175 & 27.0bcde & $27.9 \mathrm{bcd}$ & $30.5 b$ & $28.5 \mathrm{~B}$ & $41.0 \mathrm{ef}$ & $41.5 \mathrm{ef}$ & $42.1 \mathrm{ef}$ & $41.5 \mathrm{C}$ & 68.1 & 69.5 & 72.7 & $70.1 \mathrm{C}$ \\
\hline 225 & $26.6 \mathrm{bcde}$ & $24.1 \mathrm{bcde}$ & $22.3 \mathrm{e}$ & $24.3 \mathrm{C}$ & $36.1 \mathrm{f}$ & $45.7 \mathrm{e}$ & $45.8 \mathrm{e}$ & $42.5 \mathrm{BC}$ & 62.7 & 69.8 & 68.2 & $66.9 \mathrm{C}$ \\
\hline Ort. & $24.48 \mathrm{~B}$ & 26.9AB & $29.4 \mathrm{~A}$ & & $45.1 \mathrm{~B}$ & $46.8 \mathrm{~A}$ & $51.5 \mathrm{~A}$ & & $69.6 \mathrm{~B}$ & 73.7B & $80.1 \mathrm{~A}$ & \\
\hline $\mathrm{LSD}_{0.05} \mathrm{~A}$ & \multicolumn{4}{|c|}{3.41} & \multicolumn{4}{|c|}{3.37} & \multicolumn{4}{|c|}{4.70} \\
\hline $\mathrm{LSD}_{0.05} \mathrm{~B}$ & \multicolumn{4}{|c|}{$\mathrm{LSD}_{0.05} \mathrm{~A}$} & \multicolumn{4}{|c|}{3.89} & \multicolumn{4}{|c|}{5.42} \\
\hline $\mathrm{LSD}_{0.05} \mathrm{AXB}$ & \multicolumn{4}{|c|}{$\mathrm{LSD}_{0.05} \mathrm{~B}$} & \multicolumn{4}{|c|}{6.74} & & & & \\
\hline
\end{tabular}

Aynı küçük harflerle gösterilen ortalamalar arasında 0.05 seviyesinde fark yoktur. Aynı sütun ve satırdaki aynı büyük harflerle gösterilen ortalamalar arasında 0.05 seviyesinde fark yoktur. A: Substrat miktarı; B: Günlük besin çözeltisi miktarı; AxB: İnteraksiyon

Azottan meyvenin yararlanma oranına ilişkin değerler istatistiksel olarak önemli olmamakla birlikte en yüksek değer 600 ve $1030 \mathrm{~g}$ substrat ortamlarında günlük $125 \mathrm{~mL}$ besin çözeltisi uygulamasıyla; $1490 \mathrm{~g}$ substrat ortamında ise $175 \mathrm{~mL}$ besin çözeltisi uygulamasıyla elde edilmiştir. 600 ve $1030 \mathrm{~g}$ substrat ortamlarında meyvenin azottan yararlanma oranı günlük besin çözeltisi miktarı $125 \mathrm{~mL}$ 'ye arttırıldığında artış göstermiş, buna karşın 175 ve 225 mL'ye arttırıldığında domates meyvesinin azottan yararlanma oranına ilişkin değerler azalma göstermiştir. Aynı şekilde $1490 \mathrm{~g}$ substrat ortamında günlük besin çözeltisi miktarı 175 mL'ye kadar arttırıldığında verilen azottan meyvenin yararlanma oranı artmıştır. Günlük 175 ve $225 \mathrm{~mL}$ besin çözeltisi uygulamalarında 1490 g substrat ortamında meyvenin azottan yararlanma oranına ilişkin değerler istatistiksel olarak aynı bulunmuştur.

Sapta azottan yararlanma oranı substrat miktarına bağlı olarak günlük $75 \mathrm{~mL}$ besin çözeltisi dozunda $\mathrm{SA}>\mathrm{SF}>\mathrm{SO}$ şeklinde; $125 \mathrm{~mL}$ besin çözeltisi dozunda $\mathrm{SA}>\mathrm{SF}=\mathrm{SO}$ şeklinde ve $175 \mathrm{~mL}$ besin çözeltisi dozunda ise $\mathrm{SA}=\mathrm{SO}=\mathrm{SF}$ şeklinde; $225 \mathrm{~mL}$ besin çözeltisi uygulamasında ise substrat miktarına bağlı olarak $\mathrm{SA}=\mathrm{SO}>\mathrm{SF}$ şeklinde sıralanmıştır. Sapta azottan yararlanma oranı en düşük $1490 \mathrm{~g}$ substrat ortamında günlük225 $\mathrm{mL}$ besin çözeltisi uygulanmasında (36.1 $\mathrm{g} / \mathrm{saks1}$ ) görülmüştür. Sapta azottan yararlanma oranına ilişkin en yüksek değer $600 \mathrm{~g}$ substrat ortamında günlük $75 \mathrm{~mL}$ besin çözeltisi uygulanması halinde (66.1 $\mathrm{g} / \mathrm{saksi}$ ) elde edilmiştir (Şekil 2).

Substrat miktarı 600, 1030 ve 1490 g ortamlarında sapta azottan yararlanma oranı günlük besin çözeltisi miktarı arttıkça kontrole göre azalma göstermiştir. Domates bitkisinde verilen azottan meyvenin yararlanma oranı substrat ve besin çözeltisi miktarına bağlı olarak \% 20.9-37.4 arasında, sap yararlanma oranı $\%$ 36.1-66.2 arasinda, meyve+sap yararlanma oranı ise $\%$ 62.7-90.0 arasında bulunmuştur. Gübre kullanım etkinliği, bitkilerin besin elementlerini alım gücü olarak ifade edilebilir. Bu gübre etkinlik oranı azot için \%40-
60 arasında olup, en yüksek etkinliğin çoğunlukla besin elementi noksanlığı görülen ortamlara uygulanan gübrelerden elde edildiği belirtilmiştir (Karaman, 2012).

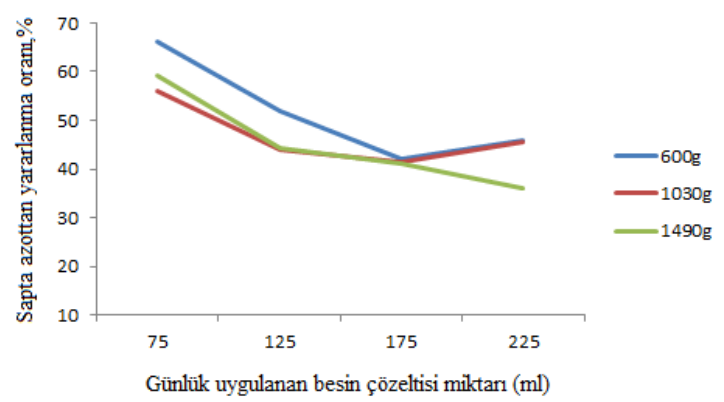

Şekil 2. Farklı miktarda substrat ortamında günlük uygulanan besin çözeltisi miktarının sapta azottan yararlanma oranına etkisi

Verilen azottan sap yararlanma oranına ilişkin değerler meyvenin yararlanma oranına ilişkin değerlerden büyük bulunmuş, verilen azotun büyük kısmının sapta bulunduğu görülmüştür. Substrat ortamına verilen azottan domatesin sap+meyvesi ile yararlandığı toplam azot oranı oldukça yüksek bulunmuştur. Bunun nedeni topraksız yetiştiricilikte besin çözeltisi uygulamalarının kontrollü şartlarda yapılması ve verilen besin elementlerinin fikse olması gibi durumlar söz konusu olmadığından dolayı uygulanan elementlerden bitkilerin çabuk ve fazla oranda yararlanabilmesinden kaynaklandığ düşünülmektedir. Ayrıca kontrollü şartlarda besin kaybındaki azalmaların da gübre kullanım etkinliğini artıracağı bildirilmiştir (Li ve ark., 2007). Halitligil ve ark (2002) damla sulama fertigasyon sistemi ile uygulanan azotun toprağın daha alt katmanlarına yıkanmasını önlediği için bitkinin azottan yararlanma oranını artırdığını ifade etmişlerdir. Ayrıca Korkmaz ve ark (1991) çeltiğin azottan yararlanma oranın en fazla başaklanma döneminde olduğunu bildirmişlerdir. Geleneksel yöntemlerle fertigasyonun kıyaslandığı 
çalışmalarda fertigasyonla gübre kullanım etkinliğinin \%20-50 daha fazla olduğu bildirilmektedir (Gaskell, 2004). Yapılan çalışmada, substrat miktarları dikkate alınmadığında günlük besin çözeltisi miktarı arttıkça meyve+sapta azottan yararlanma oranı önemli derecede azalma göstermiştir. Buna karşın günlük besin çözeltisi miktarları dikkate alınmadığında substrat miktarı azaldıkça azottan yararlanma oranı önemli derecede artmıştır.

Substrat ve günlük uygulanan besin çözeltisi miktarının domates bitkisinde meyvede, sapta ve meyve+saptafosfordan yararlanma oranına etkisi ilişkin değerler Çizelge 3 'te verilmiştir.

Çizelge 3. Substrat ve günlük uygulanan besin çözeltisi miktarının domates bitkisinde meyvede, sapta ve meyve+sapta fosfordan yararlanma oranına etkisi

\begin{tabular}{|c|c|c|c|c|c|c|c|c|c|c|c|c|}
\hline \multirow{3}{*}{$\begin{array}{l}\text { Günlük besin } \\
\text { çözeltisi } \\
\text { miktarı } \\
(\mathrm{mL})\end{array}$} & \multicolumn{4}{|c|}{ Meyvede P yararlanma oran1, \% } & \multicolumn{4}{|c|}{ Sapta P yararlanma oran1, $\%$} & \multicolumn{4}{|c|}{ Meyve+sapta $P$ yararlanma oran $1, \%$} \\
\hline & \multicolumn{3}{|c|}{ Substrat miktarı $\left(\right.$ g saks1 $\left.^{-1}\right)$} & \multicolumn{5}{|c|}{ Substrat miktarı $\left(\mathrm{g} \mathrm{saks1}^{-1}\right)$} & \multicolumn{4}{|c|}{ Substrat miktarı $\left(\mathrm{g} \mathrm{saks1}^{-1}\right)$} \\
\hline & 1490 & 1030 & 600 & Ort. & 1490 & 1030 & 600 & Ort. & 1490 & 1030 & 600 & Ort. \\
\hline 75 & $23.68 \mathrm{~cd}$ & $29.54 \mathrm{bc}$ & $29.42 b c$ & 27.54B & 42.48 & 36.01 & 41.02 & $39.8 \mathrm{~A}$ & $66.41 \mathrm{ab}$ & $65.80 \mathrm{ab}$ & $71.30 \mathrm{a}$ & $67.8 \mathrm{~A}$ \\
\hline 125 & $25.19 \mathrm{~cd}$ & $38.35 \mathrm{a}$ & $40.07 \mathrm{a}$ & $34.53 \mathrm{~A}$ & 33.10 & 28.86 & 30.98 & $30.9 \mathrm{~B}$ & $58.4 \mathrm{bc}$ & $63.21 \mathrm{ab}$ & $71.20 \mathrm{a}$ & $64.3 \mathrm{~A}$ \\
\hline 175 & $33.17 b$ & $38.54 \mathrm{a}$ & $33.74 \mathrm{ab}$ & $35.15 \mathrm{~A}$ & 32.23 & 26.37 & 27.15 & $28.5 \mathrm{BC}$ & $65.5 \mathrm{ab}$ & $61.01 b$ & $61.0 \mathrm{~b}$ & $62.5 \mathrm{AB}$ \\
\hline 225 & $34.51 \mathrm{ab}$ & $29.66 \mathrm{bc}$ & $22.17 \mathrm{~d}$ & 28.78B & 27.71 & 28.16 & 28.08 & $27.9 \mathrm{C}$ & $62.3 \mathrm{ab}$ & $57.95 \mathrm{bc}$ & $50.34 \mathrm{c}$ & 56.9B \\
\hline Ort. & 29.13B & $34.02 \mathrm{~A}$ & $31.35 \mathrm{AB}$ & & $33.88 \mathrm{~A}$ & $29.85 \mathrm{~B}$ & $31.80 \mathrm{~A}$ & & 63.14 & 61.99 & 63.46 & \\
\hline $\mathrm{LSD}_{0.05} \mathrm{~A}$ & \multicolumn{4}{|c|}{3.24} & \multicolumn{4}{|c|}{2.16} & \multicolumn{4}{|c|}{5.79} \\
\hline $\mathrm{LSD}_{0.05} \mathrm{~B}$ & \multicolumn{4}{|c|}{3.74} & \multicolumn{4}{|c|}{2.50} & \multicolumn{4}{|c|}{ - } \\
\hline $\mathrm{LSD}_{0.05} \mathrm{AXB}$ & \multicolumn{4}{|c|}{6.48} & \multicolumn{4}{|c|}{-} & \multicolumn{4}{|c|}{10.03} \\
\hline
\end{tabular}

Aynı küçük harflerle gösterilen ortalamalar arasında 0.05 seviyesinde fark yoktur.

Aynı sütun ve satırdaki aynı büyük harflerle gösterilen ortalamalar arasında 0.05 seviyesinde fark yoktur

Genel olarak verilen fosfordan sapta yararlanma oranına ilişkin değerler meyvede yararlanma oranına ilişkin değerlere yakın bulunmuştur. Meyvede fosfordan yararlanma oranı günlük $75 \mathrm{~mL}$ besin çözeltisi uygulamasında substrat miktarına bağlı olarak $\mathrm{SF}<\mathrm{SO}=\mathrm{SA}$ şeklinde; $125 \mathrm{~mL}$ besin çözeltisi uygulamasinda $\mathrm{SF}<\mathrm{SO}<\mathrm{SA}$ şeklinde; $175 \mathrm{~mL}$ besin çözeltisi uygulamasında $\mathrm{SF}=\mathrm{SA}<\mathrm{SO}$ şeklinde; $225 \mathrm{~mL}$ besin çözeltisi uygulamasında ise $\mathrm{SA}<\mathrm{SO}<\mathrm{SF}$ şeklinde sıralanmıştır. Günlük uygulanan besin çözeltisi miktarı $225 \mathrm{~mL}$ olduğunda substrat miktarı arttıkça meyvenin verilen fosfordan yararlanma oranı artmıştır. Verilen fosfordan meyvenin yararlanma oranına ilişkin en yüksek değer $600 \mathrm{~g}$ substrat ortamına günlük $125 \mathrm{~mL}$ besin çözeltisi uygulanması ileelde edilmiştir. $1490 \mathrm{~g}$ substrat ortamına uygulanan günlük besin çözeltisi miktarı arttıkça meyvede verilen fosfordan yararlanma oranı artmıştır. Buna karşın $600 \mathrm{~g}$ substrat ortamına uygulanan günlük besin çözeltisi miktarı $125 \mathrm{~mL}$ 'ye arttırıldığında meyvede fosfordan yararlanma oranı artmış; besin çözeltisi günlük $125 \mathrm{~mL}$ 'den daha fazla uygulandığın da ise azalmıştır. $1030 \mathrm{~g}$ substrat ortamında ise günlük besin çözeltisi miktarı $125 \mathrm{~mL}$ 'ye arttırıldığında meyvede fosfordan yararlanım oranı artmış; $175 \mathrm{~mL}$ 'de değişmezken, $225 \mathrm{~mL}$ 'de azalmıştır (Şekil 3).

Verilen fosfordan meyvenin yararlanma oranına ilişkin en yüksek değerler 600, 1030 ve $1490 \mathrm{~g}$ substrat ortamlarında sirasiyla, 125,175 ve $225 \mathrm{~mL}$ besin çözeltisi uygulamalarıyla elde edilmiştir. İstatistiksel olarak $600 \mathrm{~g}$ substrat ortamında günlük $125 \mathrm{~mL}, 1030 \mathrm{~g}$ substrat ortamında günlük $125 \mathrm{~mL}$ besin çözeltisi ve $1490 \mathrm{~g}$ substrat ortamında ise günlük $175 \mathrm{~mL}$ besin çözeltisi uygulamaları önemli bulunmuştur.

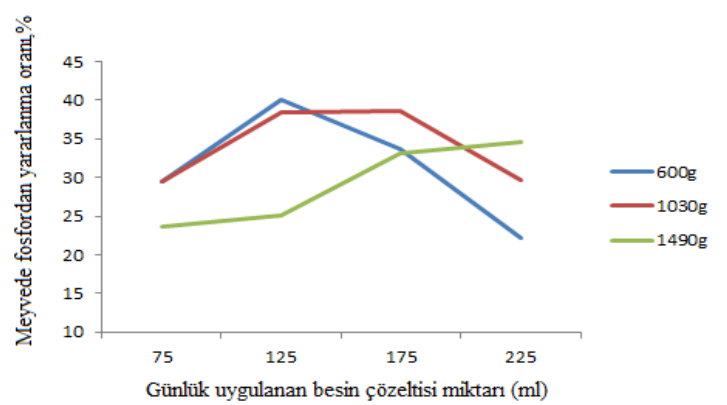

Şekil 3. Farklı miktarda substrat ortamında günlük uygulanan besin çözeltisi miktarının meyvede fosfordan yararlanma oranına etkisi

Domates bitkisinde verilen fosfordan meyvenin yararlanma oranı substrat ve besin çözeltisi miktarına bağlı olarak \% 22.17-40.07 arasında, sap yararlanma oran1 \% 26.37-42.48 arasinda, meyve+sap yararlanma oranı ise \% 50.34-71.30 arasında bulunmuştur. Gübre kullanım etkinliği, bitkilerin besin elementlerini alım gücü olarak ifade edilebilir. Bu gübre etkinlik oranı fosfor için \% 20-30 arasında olup, en yüksek etkinliğin çoğunlukla besin elementi noksanlığ 1 görülen ortamlara uygulanan gübrelerden elde edildiği belirtilmiş̧tir (Karaman, 2012).

Meyve+sapta fosfordan yararlanma oran1 $600 \mathrm{~g}$ substrat ortamında $125 \mathrm{~mL}, 1030$ ve $1490 \mathrm{~g}$ substrat ortamlarında ise günlük $225 \mathrm{ml}$ besin verilen fosfordan yararlanma oranı önemli derecede azalma göstermiştir. $1490 \mathrm{~g}$ substrat ortamında ise günlük besin çözeltisi miktarları 75, 175 ve $225 \mathrm{~mL}$ olduğunda meyve+sapta fosfordan yararlanma oranına ilişkin değerler istatistiksel olarak birbirlerine yakın oldukları halde, günlük besin çözeltisi miktarı $125 \mathrm{~mL}$ olduğunda 
meyve+sapta fosfordan yararlanma oranına ilişkin değerde diğer besin çözeltisi uygulamalarına göre azalma görülmüştür. Yapılan çalışmada günlük besin çözeltisi miktarı $225 \mathrm{~mL}$ olduğunda meyve+sapta fosfordan yararlanma oranı substrat miktarı arttıkça artmıştır. Verilen fosfordan meyve+sapta yararlanma oranına ilişkin en yüksek değer $600 \mathrm{~g}$ substrat ortamına günlük $75 \mathrm{~mL}$ besin çözeltisi uygulanması halinde elde edilmiştir.

Substrat ve günlük uygulanan besin çözeltisi miktarının domates bitkisinde meyvede, sapta ve meyve+sapta potasyumdan yararlanma oranına etkisi ilişkin değerler Çizelge 4'te verilmiştir.

Verilen potasyumdan sapta yararlanma oranına ilişkin değerler meyvede yararlanma oranına ilişkin değerlerden düşük bulunmuştur. Diğer bir ifadeyle verilen potasyumun büyük bir kısmının meyveye taşındığ 1 görülmüştür. Meyvede ve sapta potasyumdan yararlanma oranına ilişkin değerler substrat miktarına bağlı bulunmamıştır. Meyvede ve sapta potasyumdan yararlanma oranına ilişkin değerler günlük besin çözeltisi miktarıyla etkilenmiştir. Substrat miktarları dikkate alınmadığında günlük besin çözeltisi miktarı $125 \mathrm{~mL}$ 'ye arttırıldığında meyvede potasyumdan yararlanma oranı artmıș, 175 ve $225 \mathrm{~mL}$ 'de meyvede potasyumdan yararlanma oranına ilişkin değerler yakın bulunmuştur. Substrat miktarları dikkate alınmadığında sapta potasyumdan yararlanma oranı günlük besin çözeltisi miktarı $125 \mathrm{~mL}$ 'ye arttırıldığında azalmış fakat 175 ve $225 \mathrm{~mL}$ dozlarında sapta potasyumdan yararlanma oranına ilişkin değerler benzer bulunmuştur. Meyve+sapta potasyumdan yararlanma oranı substrat ve besin çözeltisi miktarlarıyla önemli derecede etkilenmemiştir. Domates bitkisinde verilen potasyumdan meyvenin yararlanma oranı substrat ve besin çözeltisi miktarına bağlı olarak \% 28.89-51.25 arasında, sap yararlanma oranı ise \% 48.60-61.35 arasında bulunmuştur. Besin elementlerinden yararlanma veya besin alım gücü olarak ifade edilen gübre kullanım etkinliği potasyum için $\%$ 65-80 arasında değişmekte olup, en yüksek etkinliğin çoğunlukla besin elementi noksanlığı görülen ortamlara uygulanan gübrelerden elde edildiği belirtilmiștir. (Karaman, 2012).

Gübre kullanım etkinliği, bitkilerin besin elementlerini alım gücü olarak da ifade edilebilir. Bu etkinlik oranının potasyum için \% 65-80 arasında değişmekte olup, en yüksek etkinliğin çoğunlukla besin elementi noksanlığ görülen ortamlara uygulanan gübrelerden elde edildiği belirtilmiştir. (Karaman, 2012).

Çizelge 4. Substrat ve günlük uygulanan besin çözeltisi miktarının domates bitkisinde meyvede, sapta ve meyve+sapta potasyumdan yararlanma oranına etkisi.

\begin{tabular}{|c|c|c|c|c|c|c|c|c|c|c|c|c|}
\hline \multirow{3}{*}{$\begin{array}{l}\text { Günlük } \\
\text { besin } \\
\text { çözeltisi } \\
\text { miktarı } \\
\text { (mL) }\end{array}$} & \multicolumn{4}{|c|}{ Meyvede $\mathrm{K}$ yararlanma oranı, $\%$} & \multicolumn{4}{|c|}{ Sapta K yararlanma oranı, \% } & \multicolumn{4}{|c|}{ Meyve+sapta K yararlanma oranı, \% } \\
\hline & \multicolumn{4}{|c|}{ Substrat miktarı $\left(\mathrm{g} \mathrm{saks1}^{-1}\right)$} & \multicolumn{4}{|c|}{ Substrat miktarı $\left(\mathrm{g} \mathrm{saks1}^{-1}\right)$} & \multicolumn{4}{|c|}{ Substrat miktarı $\left(\mathrm{g} \mathrm{saks1}^{-1}\right)$} \\
\hline & 1490 & 1030 & 600 & Ort. & 1490 & 1030 & 600 & Ort. & 1490 & 1030 & 600 & Ort. \\
\hline 75 & 28.89 & 39.77 & 37.14 & $35.36 \mathrm{BC}$ & 24.21 & 21.34 & 20.67 & $22.07 \mathrm{~A}$ & 53.15 & 61.15 & 57.86 & 57.4 \\
\hline 125 & 36.25 & 44.39 & 47.52 & $42.82 \mathrm{~A}$ & 20.26 & 15.12 & 16.61 & $17.33 \mathrm{~B}$ & 56.60 & 59.56 & 61.35 & 59.2 \\
\hline 175 & 39.30 & 39.54 & 42.0 & $40.28 \mathrm{AB}$ & 16.78 & 12.41 & 16.94 & 15.37B & 56.10 & 51.56 & 58.91 & 55.7 \\
\hline 225 & 40.1 & 32.34 & 51.25 & $34.56 \mathrm{C}$ & 16.04 & 19.43 & 17.32 & $17.59 \mathrm{~B}$ & 56.16 & 53.48 & 48.50 & 53.4 \\
\hline Ort. & 36.13 & 39.01 & 39.55 & & 19.32 & 17.07 & 17.88 & & 55.50 & 57.03 & 56.68 & \\
\hline $\mathrm{LSD}_{0.05} \mathrm{~A}$ & \multicolumn{4}{|c|}{ - } & \multicolumn{4}{|c|}{-} & \multicolumn{4}{|c|}{-} \\
\hline $\mathrm{LSD}_{0.05} \mathrm{~B}$ & \multicolumn{4}{|c|}{5.56} & \multicolumn{4}{|c|}{2.54} & \multicolumn{4}{|c|}{-} \\
\hline $\mathrm{LSD}_{0.05} \mathrm{AXB}$ & \multicolumn{4}{|c|}{ - } & \multicolumn{4}{|c|}{ - } & \multicolumn{4}{|c|}{ - } \\
\hline
\end{tabular}

Aynı küçük harflerle gösterilen ortalamalar arasında 0.05 seviyesinde fark yoktur.

Aynı sütun ve satırdaki aynı büyük harflerle gösterilen ortalamalar arasında 0.05 seviyesinde fark yoktur

\section{Sonuc}

Çalışma sonunda meyve, sap ve meyve+sap N, P ve K'dan yararlanma oranı substrat ve besin çözeltisi miktarına bağlı değişmiş̧ir. Elde edilen sonuçlara göre, verilen azottan meyvenin yararlanma oranına ilişkin optimum değer 600 ve 1030 g substrat miktarlarında $125 \mathrm{~mL}$ besin çözeltisi uygulamasıyla, $1490 \mathrm{~g}$ substrat miktarın da ise $175 \mathrm{~mL}$ besin çözeltisi uygulamasıyla elde edilmiştir. Sapta azottan en fazla yararlanma oranı en düşük substrat $(600 \mathrm{~g})$ ve besin çözeltisi $(75 \mathrm{~mL})$ miktarından elde edilmiştir. Meyve+sapta azottan yararlanma oranı azalan substrat miktarı ve besin çözeltisi miktarı ile azalma göstermiştir.

Fosfordan yararlanma oranı sapta ve meyvede birbirine yakın bulunmuştur. Verilen fosfordan meyvenin optimum yararlanma oranı 600 ve $1030 \mathrm{~g}$ substrat ortamlarında günlük $125 \mathrm{~mL}$ besin çözeltisi uygulamasıyla; $1490 \mathrm{~g}$ substrat ortamında ise günlük $175 \mathrm{~mL}$ besin çözeltisi uygulamasıyla elde edilmiştir. Günlük besin çözeltisi miktarı $225 \mathrm{~mL}$ olduğunda meyve+sapta fosfordan yararlanma oranı substrat miktarı arttıkça artmıştır. Meyve+sapta fosfordan yararlanma oranına ilișkin en yüksek değer $600 \mathrm{~g}$ substrat ortamına günlük $75 \mathrm{~mL}$ besin çözeltisi uygulanması ile elde edilmiştir.

Potasyumdan yararlanma oran1 meyvede ve sapta substrat miktarına bağlı bulunmazken, günlük besin çözeltisi miktarıyla etkilenmiştir. Yararlanma oranı sapta meyveden düşük bulunmuştur. 
Genel olarak domates bitkisine verilen azot ve fosfordan en yüksek yararlanma oranını elde etmek için meyvede $125 \mathrm{~mL}$, sap ve meyve+sapta $75 \mathrm{~mL}$ besin çözeltisi miktarları tavsiye edilirken; potasyum için meyve ve meyve+sapta $125 \mathrm{~mL}$, sapta $75 \mathrm{~mL}$ günlük besin çözeltisi miktarları tavsiye edilmiştir.

\section{Kaynaklar}

Adiloğlu, A., Eraslan, F., 2012. Bitki Besleme. 4. Bölüm Gübreler ve gübreleme tekniği. Editör M.R. Karaman, Pelin Ofset Matbaacılık, s. 347-475, Çorum.

Alam, S.M., Shah,S.A., Akhter, M., 2003. Varietal differences in wheat yield and phosphorus use efficiency as influenced by method of phosphorus application. Songklanakarin J. Sci. Tech., 25: 175-181.

Baligar, V.C., Fageria, N.K., He, Z.L., 2001. Nutrient use efficiency in plants. Communications in Soil Science and Plant Analysis, 32: 7-8.

Gaskell, M., 2004. Nitrogen availability, supply, and sources in organic row crops. Proc. California Organic Production and Farming in the New Millennium: A Research Symposium. Berkeley, CA, 15 July 2004. University of California Sustainable Agr. Res. and Educ. Program, University of California, Davis. p. 13-20.

Gerendas, J., Abbadi, J., Sattelmacher, B., 2008. Potassium efficiency of safflower (Carthamus tinctorius L.) and sunflower (Helianthus annuus L.). J Plant Nutr Soil Sci., 171:431-439.

Gül, A., 2008. Topraksız tarım. Hasat Yayıncılık, 144 s., İstanbul.

Halitligil, M.B., Antep, S., Önertoy, Ş., Kışlal, H., Şirin, H., Şirin, C., 2002. Toprak Verimliliği ve Bitki Besleme Araştırmalarında Kullanılan Izotop ve Radyasyon Teknikleri Taek-Antham Nükleer Tarım Radyoizotop Uygulama Notları, s. 31 Ankara.
Kacar, B., İnal, A., 2008. Bitki analizleri, Nobel Yayın No:1241, 892 s. Ankara.

Karaman, M.R., Turan, M., 2012. Bitki beslemede sürdürülebilir yönetim stratejisi ve gübre etkinlik parametreleri. Toprak Su Dergisi 1(1): 15-21, Ankara.

Karaman, M.R., 2012. Bitki Besleme (Editör: M.R. Karaman), Gübretaş Rehber Kitapları Dizisi:2, 685-729, Ankara.ISBN:978-605-87103-2-0.

Karaman, M.R., Şahin, S., Sert, T., 2006. Site Specific phosphorus status of wheats plants (Triticum aestivum) on calcareous soils. Journal of Revue De Cytologie Et Biologie Vegetales 28:128-134, France.

Karaman, M.R., Şahin, S., Göktolga, G., Cangi, R., 2008. Tokat yöresi bağlarında gübre kullanımında etkili sosyoekonomik faktörler. 4. Ulusal Bitki Besleme ve Gübre Kongresi, 8-10 Ekim, Bildiriler, s. 126-136, Konya.

Korkmaz, A., Halitligil , M.B., Torun, M., 1991. Determination of Urea Utilization of Rice at different Growth Stages By $15 \mathrm{~N}$ Tracer Tecnique. Turkish Journal of Nuclear Sciences, 18(2):35-46.

Li, YL., Stanghellini, C., Challa, H., 2001. Effect of electrical conductivity and transpiration on production of greenhouse tomato (Lycopersicon esculentum L.). Scientia Horticulturae 88, 11-29.

Li, X.X., Hu, C.S., Jorge, A.D., Zhang, Y.M. 2007. Increased nitrogen use efficiencies as a key mitigation alternative to reduce nitrate leaching in north china plain. Agr Water Manage., 89:137-147.

Schepers, J. S., Varvel, G. E., Watts, D. G., 1995. Nitrogen and water management strategies to reduce nitrate leaching under irrigated maize. J. Contaminant Hydrol., 20: 227239.

Yurtsever, N., 1982. Tarla deneme tekniği. Toprak ve Gübre Araştıma Enstitüsü Müdürlüğü Yayınları, Genel Yayın No. 91, Rapor Yayın No. 47. Ankara. 